\title{
AN IDEAL ARCHAEOLOGICAL, CULTURAL AND ECOLOGIC TOUR IN THE NILE DELTA*
}

\author{
Dr. Omaïma El-Shal**
}

\begin{abstract}
This study is chosen to highlight The Nile Delta in different tourist programs. It focuses on Nile Delta trumps. By presenting different cities and natural sites forgotten or unknown for most tour operators who promote Egypt, the study is trying to coordinate an ideal ecological, archeological and cultural tour in The Nile Delta. This presentation is a descriptive and qualitative study.

The presentation will present a trip across the Egyptian Delta that covers different details about natural and archeological sites and different accommodations in each part. The research is based on analyzing tour programs on websites and reviewing principal natural, historical and archeological sightseeing in the Nile Delta to see if it is necessary to add them in-tour programs. As for the literature, it is specificaly based on personal field experience, The Annual Book of the Ministry of Information, Service of Information of States (SIS), and specialized references in Tourism and Egyptology.
\end{abstract}

* This paper was presented during the 2012 TOSOK International Tourism Conference, organized by Tourism Sciences Society of Korea (TOSOK), 4-6 July 2012.

** Associate Professor, Head of Tourism Guidance Department, Faculty of Archaeology and Tourism Guidance, Misr University for Science and Technology (MUST) - Egypt.

$-7-$ 
This presentation will give a new idea about The Nile Delta in Egypt and will also present a new approach to discovering it from different domains. It will show how sustainable tourism can be promoted in The Nile Delta in Egypt.

Key Words: Egypt; Tourism; Nile Delta; Tourism industry.

\section{Introduction}

The Tourism industry represents one of the main sources of the national income in Egypt ${ }^{(1)}$. It is associated with about 70 feeder and complementary services and industries. The Egyptian State Information Service declares that tourism represents $11.3 \%$ of Egypt's GDP, $40 \%$ of the total Egypt's non-commodity exports in 2007/2008 and $19.3 \%$ of Egypt's foreign currency revenues. It is also one of the most laborintensive activities representing $13 \%$ of the labor force. The contribution of the tourism sector in GDP in 2008/2009 reached about 3.6\% $\%^{(2)}$.

After the $25^{\text {th }}$ of January 2011 Revolution, the collapse of tourism was quite natural. But fortunately, the United Nations World Tourism Organization (UNWTO) announced that the number of tourists visiting Egypt in the first two months of 2012 increased by 32 percent compared to the same period last year, after the events of the $25^{\text {th }}$ of January $2011^{(3)}$. However, the number of tourists (753.000) is still not up to their number of February 2010 that hit 1.1 million $^{(4)}$.

While the Nile Delta in Egypt has a lot of trumps which can be a good promotion, it is completely forgotten, especially from the "Cultural Tourism" page of the SIS website. Therefore, it was necessary to find ways to promote it. During the last TOSOK conference, we presented a

(1) O. EL-SHAL, "Archaeological and Environmental Solidarity Tourism for Developing the Egyptian Village in the Nile Delta", The 2011 TOSOK International Tourism Conference, organized by Tourism Sciences Society of Korea (TOSOK), Seoul, 4-6 July 2011.

(2) Ministry of Information, Service of Information of States, Arab Republic of Egypt, The Annual Book 2009, Cairo: Service of Information of States Publications.

(3) www.sis.gov.eg/En/FourStTemplate.aspx?Category_ID=436 (February $22^{\text {nd }} 2012$ ).

(4) Ibid. 
study for archaeological and environmental solidarity tourism for developing the Egyptian village in the Nile Delta with an approach to the different details ${ }^{(1)}$; and for the new edition, we wanted to see the situation of the Delta on the tourist map.

\section{Literature Review}

\section{Tours in Egypt}

Tours' itineraries are usually predictable. They include: sightseeing of Cairo and Upper Egypt (Luxor and Aswan) and exclude the Nile Delta, even if the Oases are included. From our long experience as tour guides since 1991, the classical tours are generally as follows:
a. Number of nights: 7
Luxor: 2 nights
Aswan: 1 night
Cruise: 4 nights
Optional: Aswan, Cairo, Red Sea

b. Number of nights: 9

Cairo: 3 nights

Aswan: 2 nights

Cruise/Aswan: 1 night

Cruise/Esna: 1 night

Cruise/Luxor: 2 nights

c. Number of nights: 12

Cairo: 3 nights

Aswan: 2 nights

Cruise/Esna: 1 night

Cruise/Luxor: 2 nights

Cruise/Qena: 1 night

Cruise/Luxor: 1 night

Luxor: 2 nights

II. The Importance of The Nile Delta

A previous study presented the different characteristics of the Nile $\operatorname{Delta}^{(2)}$.

(1) O. EL-SHAL, loc. cit.

(2) Ibid. 


\section{The importance of the Nile Delta in ancient history:}

After the emergence of shepherding and agriculture about 6000 $\mathrm{BC}$, villages appeared in the South of the Delta ${ }^{(1)}$. In the end of the pre-dynastic period, Egyptians controlled the road to the North Sinai ${ }^{(2)}$. Commercial relations between Egypt and the Levant had begun by this time ${ }^{(3)}$, and due to the increase of imported products, establishment of commercial installations in the Oriental Delta and some maritime roads were required ${ }^{(4)}$. Around $3400 \mathrm{BC}$, the dryness obliged Sinai inhabitants and those South of the Levant to settle in the Oriental Delta where urbanization had became developed till the Occidental Delta ${ }^{(5)}$.

The Delta, nicknamed the Nile's daughter ${ }^{(6)}$, played an increasingly important part in the economy, politics and culture of Egypt during the dynastic periods to the Ptolemaic times (3100-30 BC). The course of the river with its branches through Lower Egypt has almost completely erased the history of that $\operatorname{area}^{(7)}$.

During the $1^{\text {st }}$ dynasty (3100-2890 BC), a lot of agglomerations had been founded in the North of Sinai ${ }^{(8)}$ and the mining of copper and turquoise had begun. Theses ores had been commercialized from the same $\operatorname{road}^{(9)}$. Relations between the Delta and the East continued during all the Old Kingdom. But in the end of the $6^{\text {th }}$ dynasty, there were some political problems which forced foreigners to be detained in

(1) F. HASSAN, "Relations culturelles entre l'Égypte et ses voisins orientaux durant la Préhistoire récente", in Le Sinaï durant l'antiquité et le Moyen Âge : 4000 ans d'histoire pour un désert, Actes du colloque « Sinaï » UNESCO from 19 to 21 september 1997, Paris, Errance, 1998, p. 17.

(2) D. VAlBelle, Les neuf arcs. L'Égyptien et les étrangers de la préhistoire à la conquête d'Alexandre, Paris, Armand Colin, 1990, p. 78

(3) Ibid., p. 57.

(4) F. HASSAN, op. cit., p. 18.

(5) Ibid.

(6) J. LozACH, Le Delta du Nil. Étude de géographie humaine, Le Caire, Société Royale de Géographie d'Égypte, 1935, p. 9.

(7) www.touregypt.net/delta2.htm (November $10^{\text {th }} 2011$ )

(8) D. VALbelle, op. cit., p. 54.

(9) Ibid., p. 56. 
the Delta until the Middle Kingdom during which new commercial and political agreements were taken up again ${ }^{(1)}$.

With the Hyksos invasion (during the $2^{\text {nd }}$ Intermediate Period 1650 - 1550 BC), the Egyptian capital was based in the East of the Delta and especially at Avaris, known today by Tell el-Dab'a in the Sharqueya governorate. The Delta became more developed until the Hyksos withdrawal. When Avaris failed, the Delta lost its importance until the $19^{\text {th }}$ dynasty when the North of Egypt came back to the historical Egyptian scene thanks to Ramses I, founder of the $19^{\text {th }}$ dynasty $\left(1295\right.$ - 1294 BC) who came from Qantir ${ }^{(2)}$ (a few kilometres from Tell el-Dab'a). By the time of the New Kingdom (1550-1069 $\mathrm{BC})$, the draining of the Delta provided a cultivation area that was twice the size of the entire Nile Valley ${ }^{(3)}$.

During the $3^{\text {rd }}$ Intermediate Period and the Late Period (1069-332 BC), the Delta came back again to the political scene. It had several capitals during this long period: Tanis (known nowadays by San elHagar), Bubastis (Tell Basta), Saïs (Sa el-Hagar).

Alexander the Great founded Alexandria as the new Egyptian capital on the Mediterranean coast. It stayed the capital until the Arab conquest.

Today, Egypt is divided up to 27 governorates, 9 of which are in the Delta:

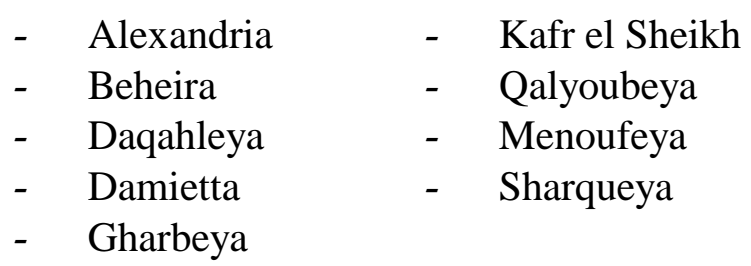

(1) Ibid., pp. 80-81, 85-89.

(2) N. GRIMAL, Histoire de l'Egypte ancienne, Paris, Fayard, 1988, p. 321.

(3) www.touregypt.net/delta2.htm (November 10 ${ }^{\text {th }} 2011$ ). 


\section{Most important cities in the Nile Delta:}

Some big cities like Alexandria are ignored in this study. The following ones, listed alphabetically, are those which have historical or archaeological importance. Due to their locations, it is very difficult to even give them a short description. However, the SIS website doesn't mention any city of the Nile Delta except Alexandria, the biggest city ${ }^{(1)}$. The main cities in the Nile Delta are as follow: Belbeis, Damanhur, Damietta, El Mahallah el-Kobra, Mansura, Rosetta, Tanta and Zagazig.

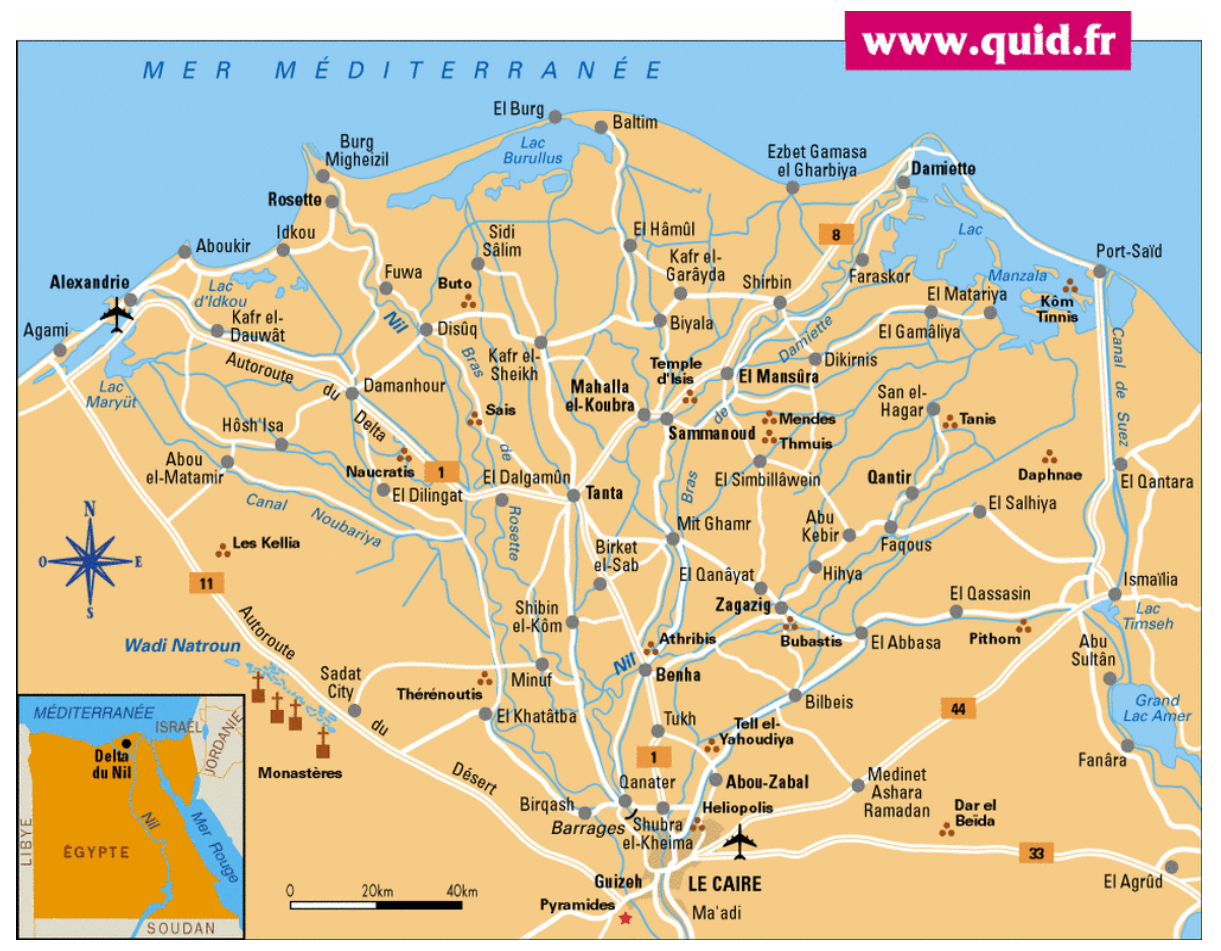

Figure 1. Map of The Nile Delta.

\section{Tourism in the Nile Delta}

Most of tourism's domains can be offered by the Nile Delta's trumps.

(1) www.sis.gov.eg/En/Story (June $2^{\text {nd }} 2012$ ) 


\section{Cultural Tourism:}

Cultural tourism is defined as a form of tourism whose object is, among other aims, the discovery of monuments and sites. It exerts on these, a very positive effect in so far as it contributes - to satisfy its own ends - to their maintenance and protection. This form of tourism justifies in fact the efforts which say maintenance and protection demands on the human community because of the socio-cultural and economic benefits which they bestow on all the populations concerned $^{(1)}$. Since the 80 's, cultural tourism has been considered an important source of economic development for many destinations ${ }^{(2)}$. Cultural heritage tourism is one of the most salient elements of the global tourism system. There is no difference between cultural tourism and heritage tourism ${ }^{(3)}$.

Even if cultural heritage tourism is concentrated in the Nile Valley, the Nile Delta is also known for Ancient Egyptian sightseeing, but less popular than sightseeing of the Nile Valley.

\section{a. The Most important ancient sites in The Nile Delta:}

Sites in southern Egypt have passed the wrath of time more favorably than those of the Delta. Greater sites in the north may have been lost under thick alluvial layers and by modern urbanization. That is why, if someone wants to make an archaeological visit, he should not expect great constructions, but ruins. So, among the most important ancient sites, which ruins are still in place, there are Tell Basta (Bubastis), San el-Hagar (Tanis), Sa el-Hagar (Sais), Behbeit elHegara (Iseum), Tell el-Ruba (Mendes) and Tell el-Yahoudeya. It is easy for the reader to find documentation about these sites if he navigates through the web. Several museums can also be visited near some of these ancient sites.

(1) www.icomos.org/tourism/ (April 22 $2^{\text {nd }} 2012$ )

(2) The Impact of Culture on Tourism, OECD, Paris, French translation of pp. 3-75, only available on Internet (November $\left.15^{\text {th }} 2012\right)$, p. 15.

(3) D.J. TiмотнY, Cultural Heritage and Tourism. An Introduction, Charlesworth, 2011, p. 6,8 . 


\section{b. Modern sightseeing:}

Beside the ancient sites, there are some new ones which can be visited like the Zifta Dam on the Damietta branch of the Nile, some $25 \mathrm{~km}$ east of Tanta. It was built in 1903 , with 50 sluice gates $5 \mathrm{~m}$ wide. It regulates the irrigation of the governorates of Gharbeya, Daqahleya and Sharqueya in The Eastern Delta ${ }^{(1)}$. Tourists can also visit the papyrus plantations near the ancient remains of Toukh el-Qaramous which are located $18 \mathrm{~km}$ west of Zagazig in the Sharqueya governorate.

\section{Recreational Tourism:}

The Mediterranean littoral of the Delta is $270 \mathrm{~km}$ long. All the way along, beach resorts have been erected one after the other like Ras el-Bar, Baltim and Gamassa. Most of these resorts are in very bad condition and need to be restored, to be brought up todays' standards and they need to be promoted, especially as modern tourist beach resorts on the North coast take all the spotlight today. The most famous tourist village on the North coast is Marina which has its' cheaper apartments costing no less than $50000 \mathrm{U \$}$.

\section{Solidarity Tourism (tourism for development):}

For this domain, the reader is invited to consult the paper presented during the TOSOK conference $2011^{(2)}$.

\section{Religious Tourism:}

Religious tourism is one of the most understudied areas in Tourism Research $^{(3)}$. It is also one of the most prevalent forms of heritage tourism in the developing world ${ }^{(4)}$. D.H. Olsen and D.J. Timothy ${ }^{(5)}$ propose that venerated places are now being seen as tourism resources that can be

(1) www.planetware.com/tourist-attractions/egypt/behbeit-el-hagara-egy-daqbehhag.htm (November $11^{\text {th }}$ 2011)

(2) O. EL-SHAL, loc. cit.

(3) D. H. OlSEN and D.J. TIMOTHY, "Tourism and religious journeys", in D.J. Timothy and D. H. Olsen, Tourism, religion and spiritual journeys, New York, Routledge, 2006, p. 1.

(4) D.J. TIMOTHY and G.P. NYAUPANE, Cultural Heritage and Tourism in the Developing World: A Regional Perspective, New York, Routledge, 2009, p. 8.

(5) D. H. OlSEN and D.J. TIMOTHY, loc. Cit. 
commoditized for travelers interested in cultural and historic sites. According to the word tourism defined by the World Tourism Organization (WTO), pilgrims and religious tourists fit in the same definition ${ }^{(1)}$. Two different kinds of religious sites were identified: shrines and pilgrimage sites. R. Blackwell ${ }^{(2)}$ described these shrines as sites where a relic or image is 'venerated', whereas pilgrimage sites are places where it is recognized that a miracle has occurred, still occurs and may do so again. In Egypt, both kinds are known for Christians and Muslims as it will be described later. But beside the sacred sites, there were also two events from the history of humanity:

- The Exodus,

- $\quad$ The advent of the Holy Family to Egypt.

Following are the most famous religious sites in the governorates of the Nile Delta:

\section{a. Christian monuments}

- Damietta: Sainte Demiana monastery

- Sharqueya: The Virgin Marys' tree in Belbeis which is a sacred place nowadays.

- Gharbeya:

- Mari Gerges church at Hesset Berma

- The Virgin Marys' church at Samannoud where the Holy Family were received by the local population with kindness and hospitality. There is in Samannoud, to this day, a large granite trough which, according to local belief, was used by the Virgin for kneading dough, and a water-well, which the Christ Child Himself has dug ${ }^{(3)}$.

(1) R. BLACKWELL, "Motivations for religious tourism, pilgrimage, festivals and events", in: R. Raj and N.D. Morpeth (ed.), Religious Tourism and Pilgrimage Festivals Management: An International Perspective, Cambridge, CAB International, 2007, p. 36.

(2) Ibid., p. 37.

(3) www.touregypt.net/holyfamily3.htm (November $10^{\text {th }} 2011$ ) 
- Kafr el Sheikh

- The Virgin Marys' church in Sakha (Coptic name Pekha Issous which means the foot of Jesus), because the Holy Childs' foot-print was marked, in a bas-relief on a rock. The rock was preserved, but hidden for centuries for fear of robbery, and appeared again 13 years ago ${ }^{(1)}$.

- Beheira: Wadi Natroun monasteries

\section{b. Islamic monuments:}

Egypt is one of the worlds' richest countries with several Islamic monuments. In the Nile Delta, there are a lot of Islamic monuments like houses, citadels, mosques and maqam - which are tombs for saints. These monuments are situated in different cities and villages.

\section{- Damietta}

- Amr Ibn el As mosque (Abou el Maati mosque)

- El Matbouli mosque

- Shata mosque Gamal el Din Shiha mausoleum

- Daqahleya

- Mowafi mosque

- El Ghemary mosque

- Dar Ibn Loqman

- Gharbeya

- $\quad$ Sayed Ahmad el-Badawi mosque

About two million people from around the Delta and other parts of the Arab world come for the mawlid of Sayed Ahmad el-Badawi, which is an eight-day celebration regulated by the Lunar Islamic Calendar like all Muslim mawlids. The mawlid is conducted around the mosque and tomb of Sayed Ahmad el-Badawi ${ }^{(2)}$. The term mawlid refers to Egypts' annual patronal feasts and pilgrimages to the graves of the principal saints. It is a feast day celebrated in honor of a saint, in

(1) Ibid.

(2) www.dar-sirr.com/Badawi.html (22 ${ }^{\text {nd }}$ April 2012) 
a given place at a specific time ${ }^{(1)}$. Etymologically and literally, a mawlid is a birthday ${ }^{(2)}$. S. Schielke ${ }^{(3)}$ describes as follows:

In the narratives of pilgrims and visitors, the mawlid indeed emerges as a utopian moment beyond the boundaries of daily life, a place where all people from all classes of society unite and where the mystic and the thief come together in the realm of the saint - a beautiful congregation with the Sûfî brethren, a moment of freedom far removed from home and daily routines.

The mawlid is not considered to be a proper custom by many Muslims as it is not part of the religion, but rather a popular tradition of the Muslim life. However, there are Coptic (Christians) mawlids also, but less known in different parts of the Delta and the Nile Valley.

- Kafr el Sheikh

- Ibrahim el Desouqui mosque

- Beheira

- $\quad$ Moulid of Sheikh Abu Rish

- Kaytbey citadel in Rosetta where The Rosetta stone was discovered by the French officer Bouchard in 1899

- Rosettas' mosques: Zaghloul mosque, Mohammed Tuleti mosque, Mohamed Abbasi mosque

- Wall of the ancient Rosetta

- Rosettas' preserved old houses of the $17^{\text {th }}-19^{\text {th }}$ centuries

- Menoufeya

- $\quad$ Sidi Mohamed Shebl el-Assouad mosque and his mawlid

\section{Therapeutical and Medical Tourism:}

Medical tourism, a term that can also be used to describe medical outsourcing, is characterized by traveling away from ones' home region

(1) C. MAYEUR-JAOUEN, Histoire d'un pèlerinage légendaire en Islam, Paris, Aubier, 2004, p. 11, 243.

(2) Ibid., p. 117; D. PAGES-El KArouI, Villes du delta du Nil: Tantâ, Mahalla, Mansûra, cités de la densité. Le Caire: CEDEJ, 2008.

(3) S. SCHIELKE, "On snacks and saints: when discourses of rationality and order enter the Egyptian mawlid”, Archives de Sciences Sociales des Religions 135, 2006, p. 120. 
to procure treatment in another. It may take one of two forms: obligatory or elective ${ }^{(1)}$.

Egypt is considered one of the richest environments of therapeutic value by virtue of its natural resources, dry warm weather and lots of mineral and sulphuric springs and black curative sands.

Egypt Touristic Guide ${ }^{(2)}$ describes Garby near Ras el-Bar, in Damietta governorate, on the Damietta branch as one of the most famous place for therapeutic treatment. It has warm and dry sand effective for the treatment of rheumatism.

Medical tourism in the Nile Delta is famous for the Mansura Urology and Nephrology Centre, in Mansura University (Daqahlia governorate). It's known by Mansura International Center for kidney diseases and International center for kidney diseases and renal dialysis in Egypt and the Middle East. It is the second centre in this area of medicine in the world ${ }^{(3)}$. Between March 1976 and March 2004, 1600 live-donor kidney transplantations were carried out in this centre ${ }^{(4)}$.

\section{Ecotourism:}

After analyzing 85 separate definitions, D. Fennell ${ }^{(5)}$ gave the following one: Ecotourism is a sustainable, non-invasive form of naturebased tourism that focuses primarily on learning about nature first-hand, and which is ethically managed to be low-impact, non-consumptive, and locally oriented (control, benefits and scale). It typically occurs in natural areas, and should contribute to the conservation of such areas. Ecotourism is considered to have important benefits for those who take part in it, both tourists and people living in the $\operatorname{area}^{(6)}$.

(1) http://www.traveldoctoronline.net/medical-tourism-and-reproductive-outsourcing--thedawning-of-a-new-paradigm-for-healthcare-MTc1NjY1NjY=.htm (April 22 ${ }^{\text {nd }} 2012$ )

(2) Egypt Touristic Guide, 2006, p. 104 (in Arabic).

(3) www.dakahliya.gov.eg/tourism.htm (23 ${ }^{\text {rd }}$ September 2011)

(4) http://www.ncbi.nlm.nih.gov/entrez/query.fcgi?cmd=Retrieve\&db=PubMed\&list_uids= $16791608 \&$ dopt $=$ Abstract $\left(22^{\text {nd }}\right.$ April 2012)

(5) D. FEnNELL, Ecotourism, $3^{\text {rd }}$ ed., New York, Routledge, 2008, p. 24.

(6) R.K. HITCHCOCK , "Cultural, Economic, and Environmental Impacts on Tourism Among Kalahari Bushmen", in E. Chambers (ed.), Tourism and Culture. An Applied Perspective. New York, State University of New York Press, 1997, p. 94. 
Opposite to the idea, ecotourism is present in several places in the Nile Deltas' protected areas which have a typical Mediterranean climate, with winter temperatures between $12^{\circ} \mathrm{C}$ and $20^{\circ} \mathrm{C}$ and summer temperatures between $18^{\circ} \mathrm{C}$ and $33^{\circ} \mathrm{C}$. The annual rainfall averages $75-150 \mathrm{~mm}$. The Egyptian Environmental Affairs Agency is managing and protecting these areas ${ }^{(1)}$.

- Zaranik Protected Area

Zaranik Protected Area is located at the eastern end of Lake Bardawil on the Mediterranean coast of Sinai. It covers about 250 sq km, $68 \%$ water surface and $32 \%$ sand dunes ${ }^{(2)}$.

- $\quad$ El Burullus Lake Protected Area

It is situated northeast of the Rosetta branch of the River Nile. It extends $10 \mathrm{~km}$ in length and 6-17 km in width. It is about $460 \mathrm{sq}$ $\mathrm{km}$, and it is considered the second largest natural lake in Egypt.

- Ashtoum el Gamil Protected Area

It is located at $7 \mathrm{~km}$ west of Port Said on Port Said-Damietta coastal road. It is a nature reserve of $180 \mathrm{sq} \mathrm{km}^{(3)}$.

- Ponds in Sharqueya governorate ${ }^{(4)}$

There are ponds in Sharqueya governorate which can be a natural reserve for birds migrating from the end of November until midMarch:

- $\quad$ Akiyad pond (84 sq km) in marquaz Faqous

- El Nasr pond (630 sq km) in marquaz el Hussayneya

- El Mohafza (governorate) pond $\left(83 \mathrm{~km}^{2}\right)$ in marquaz el Hussayneya.

\section{Sports Tourism:}

Authors agree that sports tourism has taken place since thousands of years ${ }^{(5)}$. The Ancient Egyptians engaged in sports with the intention of training and strengthening their bodies, and also for pleasure and recreation.

(1) www.sis.gov.eg/En/Tourism/Egyptall/Enviormental/ (November 11 ${ }^{\text {th }} 2011$ )

(2) www.touregypt.net/parks (23 ${ }^{\text {rd }}$ May 2012)

(3) www.sis.gov.eg/En/Story.aspx?sid=1058 (23 ${ }^{\text {rd }}$ May 2012)

(4) www.sharkia.gov.eg/gov_achiev_tour.asp (23 ${ }^{\text {rd }}$ May 2012)

(5) M. WEED, Sport \& Tourism: A Reader, New York, Routledge, 2008, p. 1. 
Many of todays' sports were practiced by the Ancient Egyptians, who actually set the rules and regulations for them. Inscriptions on monuments indicate that they practiced wrestling, weightlifting, long jumping, swimming, rowing, shooting, fishing and athletics, as well as various kinds of ball games.

Nowadays, sports tourism is one of the different domains of tourism. H.J. Gibson ${ }^{(1)}$ suggested definition for sports tourism:

Leisure-based travel that takes individuals temporarily outside of their home communities to participate in physical activities, to watch physical activities, or to venerate attractions associated with physical activities.

In the past few years, sports like hockey, horse riding and camel racing have became popular in the Delta. These sports are played frequently in Sharqueya governorate ${ }^{(2)}$.

- Hockey (in the past, there was a sport like hockey named "hoksha")

The Sharqueya hockey team is one of the best in Egypt.

\section{- Horse Riding}

Introduced by the Hyksos about $1650 \mathrm{BC}$, horses were used especially for war-chariots and wheel-mounted war weapons. Nowadays, Arabian horses are one of the most sought after pedigrees in the world. The governorate symbol of Sharqueya represents a wild white horse. Since 1991, there is a big popular festival for Arabian horses at Belbeis city. Every year the governorate of Sharqueya greets thousands of Egyptian, Arab and foreign tourists. Festivals and competitions are conducted in the horse riding resort $(63000 \mathrm{sq} \mathrm{m}$, investment 1.14 million $\mathrm{U} \$$, exploiting for 50 years) which is composed of a racecourse, a training centre and stables.

(1) H.J. GIBSON, "Sport Tourism: A Critical Analysis of Research", Sport Management Review 1 (1), 1998, p. 49.

(2) www.sharkia.gov.eg/gov_achiev_tour.asp $\left(23^{\text {rd }}\right.$ May 2012) 
- Camel Racing.

For many years, Arab tributes were set up in Sharqueya governorate. They breed camels with Arabian pedigrees. They organize Camel Racing events and participate with other governorates.

- Gazelle and Duck Hunting

Sharqueya governorate and Shakhlouba area in Kafr el-Sheikh governorate $^{(1)}$ are famous for gazelle and duck hunting.

\section{Conference Tourism:}

National and international conferences are held in different Delta cities. There are more than 500 seminars and conferences held each year in Sharqueya governorate ${ }^{(2)}$. Other Delta governorates may follow the same initiative.

\section{Desert (Safari) Tourism:}

The desert is becoming increasingly a popular touristic destination ${ }^{(3)}$. Desert tourism can be a sustainable development solution and can help combat desertification $^{(4)}$. The edges of the Delta can be profit for this kind of tourism. Sharqueya governorate is situated at the extreme east of The Nile Delta. Besides fields, it has large desert which can be used for safaris, beach buggy journeys (or racing) and falcon hunting.

\section{Method}

This study was conducted on tour operators programs on their websites. It was realized after the revolution of January $25^{\text {th }} 2011$. To conduct this research, a questionnaire was designed to measure the Nile Deltas' sites in programs. What are the sites visited in the Nile Delta? What is the frequency of the sites on the programs? The tour operators were American and French. Also, the Egyptian State Information Service (SIS) and the Egyptian Official Tourism websites were analyzed to see where the Nile Delta is positioned on the tourist map ${ }^{(5)}$.

(1) Egypt Touristic Guide, May 1996, p. 98, 99 (in Arabic).

(2) www.sharkia.gov.eg/gov_achiev_tour.asp (23 ${ }^{\text {rd }}$ May 2012)

(3) V. Lefebvre, S.G. Miller, and A. Chaouni, Desert Tourism: Tracing the Fragile Edges of Development, Harvard University Press, 2011.

(4) United Nations Environment Program, Tourism and Deserts: A Practical Guide to Managing the Social and Environmental Impacts in the Desert Recreation Sector, 2006.

(5) www.en.egypt.travel (May 15 ${ }^{\text {th }} 2012$ ); www.sis.gov.eg/En/Story (June $2^{\text {nd }} 2012$ ) 


\section{Results}

By analyzing the Egyptian State Information Service (SIS) and the Egyptian Official Tourism websites, it appeared that there was no reference at all to the Nile Delta. The section "Where to go" in the Egyptian Official Tourism website was giving only four sectors: the Nile Valley, the White Med, the Red Sea and the Western Desert ${ }^{(1)}$. The cities of the Delta, except for Alexandria which is the second city in Egypt, are excluded from the famous cities mentioned by the Ministry of Tourism ${ }^{(2)}$ and the Egyptian State Information Service which is the leader for the promotion of Egypt on the website.

The link museum ${ }^{(3)}$, one of the links of the Egyptian Tourism Authorities, presents 61 museums in Egypt, of which 7 are located in the Delta, and none of them have a website: El Mansura museum (Dar Ibn Loqman), San el-Hagar museum, Hariya Razna Museum (Zagazig), Ahmad Orabi museum (Zagazig), Donshway museum, Rashid Museum (Rossetta) and Ismailia Museum. (Only 3 provided their phone numbers). As for the attractions cited, they only mention some sightseeing in Alexandria.

\section{Marketing the Nile Delta}

The Nile Delta and its main cities are often forgotten by tour operators. For many years, I have worked as a tour guide in Egypt and I have never led a group in the Delta. Only once, I joined a group whose program included the Delta. It was a special group organized by a French tour operator and was led by the most famous French Egyptologist, Professor Jean Yoyotte. The trip was for one week from the $7^{\text {th }}$ to the $14^{\text {th }}$ of December 1996. Since then, I looked for programs including sightseeing in the Nile Delta but in vain, I eventually had to organize my own trips to the Nile Delta.

By studying and analyzing different tours of twelve French tour operators websites, even sites which give the opportunity to organize a

(1) www.en.egypt.travel (May $15^{\text {th }} 2012$ )

(2) www.egypttourism.org ( $22^{\text {nd }}$ April 2012)

(3) www.tourism.egnet.net/culture/museums_Egy.asp (November $10^{\text {th }} 2011$ ) 
private tour like Evaneos ${ }^{(1)}$, it turned out that no French tour operator offers a regular tour in the Nile Delta during a long trip. The American tour operators don't give any information for the Delta. So to visit the Nile Delta, it is essential to organize one yourself. From twelve tour operators, five (Clio, Voyage à thème, Terra trips, Grepal, Arvel Voyages) propose Delta trips and usually organize theme tours. The ancient site of Tanis, nowadays San el-Hagar, is always included in programs. Rosetta and Mansura are cited three times, Bubastis (Tell Basta today) twice. Voyage à thème and Terra trips offer in their tours, a discovery of protected areas like El-Borollous Lake Protected Area and the biggest pigeon loft in Egypt, near the small city of Qotour. They offer four days in the Nile Delta, while the others propose only one day. During the tour of Clio, there are two days in the Nile Delta.

\section{Archaeological Trips in the Nile Delta}

This paper is focusing on the historical and archaeological sightseeing. As said above, the Delta has a lot of trumps which can be a good promotion for it. When this subject was chosen, we wanted to highlight the Nile Delta in the different touristic programs. It's true that most of the people who decide to visit Egypt have a limited time to spend in Egypt. We saw that classical tours range between 7 and 12 days. That is why we found that it is better to present a trip to the Nile Delta which can be a pioneer. This trip will cover the most famous historical sites. No notice of Cairo visits is mentioned. Only Alexandria is mentioned. Beside the archaeological sites, some of Delta's trumps are taken into consideration to have an ideal program in the Delta.

\section{The ideal tour program in the Nile Delta}

\section{First day:}

- Arrival at Cairo and check in

- Conference given by the tour guide using: A power point presentation, maps and pictures

\section{Second day:}

- Departure from Cairo by bus

- Visit of Tell el-Yahoudeya (Sharqueya Governorate)

(1) www.evaneos.com/egypte ( $22^{\text {nd }}$ April 2012) 
- A Stop at Belbeis to see the Virgin Marys' tree (Sharqueya Governorate)

- Visit of Tell Basta (Sharqueya Governorate)

- Lunch in a local restaurant at Zagazig (Sharqueya Governorate)

- After lunch, a visit to the Ahmad Orabi Museum in Zagazig, followed by a visit to a papyrus plantation at Toukh el Qaramous (Sharqueya Governorate)

- Dinner and a folklore show at Ismailia

- An overnight stay in Ismailia

\section{Third day:}

- Check out from Ismailia

- Visit of the ruins of San el Hagar (Tanis) in Sharqueya Governorate

- A barbecue lunch with Bedouins in the desert and an Arabian horse show

- A visit to the Ashtoum el Gamil protected area

- An overnight stay in the Gamassa resort (Daqahleya Governorate)

\section{Fourth day:}

- Check out from the Gamassa resort

- A visit to The Saint Demiana Monastery and Amr Ibn el-As mosque (Abou el Maati mosque) in Damietta (Damietta Governorate)

- Lunch in a fish restaurant at Damietta

- An afternoon trip to the remains of The Isis temple in Behbeit el Hegara and Tell el Rub'a (Daqahleya Governorate)

- An overnight stay in Mansura and meeting with doctors to talk about the famous hospital or visit the garden (Daqahleya Governorate)

\section{Fifth day:}

- Check out from The Mansura hotel

- In the morning, a visit to Dar Ibn Loqman Museum in Mansoura (Daqahleya Governorate)

- A visit to the Virgin Marys' church at Samannoud (Gharbeya Governorate) where the Holy Family were received by the local population with kindness and hospitality

- A lunch with an Egyptian family 
- A visit to a factory of knitting and weaving in Mehalla el Kobra (Gharbeya Governorate)

- An overnight stay in Tanta (Gharbeya Governorate)

\section{Sixth day:}

- Check out from the Tanta hotel

- In the morning, a visit to The Sayed Ahmad el-Badawi mosque at Tanta (Gharbeya Governorate)

- $\quad$ Stop to see the remains of Sa el-Hagar (Sais)

- Visit The Virgin Marys' church in Sakha (Kafr es-sheikh Governorate) where the Holy child's foot-print was marked, in basrelief on a rock

- Lunch in local restaurant at Rosetta (Beheira Governorate)

- In the afternoon, a visit to the Kayetbey Citadel, Rosetta mosques and old houses of the 17th -19 th centuries

- An overnight stay in Alexandria

Seventh day:

- A trip to the different sights of Alexandria (Roman Theatre, Pompeii Column, Catacombs of Kom el Shokafa, The New Alexandria Library and The National Museum of Alexandria

- An overnight stay in Alexandria

Eighth day:

- Return to Cairo by the Desert Road and a visit to The Wadi El Natroun Monasteries

- $\quad$ Or a trip to The Dima plantations

- An overnight stay in Cairo

\section{Ninth day:}

- Final departure

\section{Conclusion}

The study aims to review where the Nile Delta is situated on the tourist map. The elaborated program tour covers seven governorates of the Nile Delta's nine governorates, if Alexandria is excluded. This proves that this part of Egypt can be a destination for a trip but it needs more promotion from Egyptian authorities and tour operators. Solidarity 
tourism can be developed if it is specifically designed. Touring the Nile Delta is suitable for both Egyptian and foreign tourists alike.

\section{References}

- R. BLACKWELL, "Motivations for religious tourism, pilgrimage, festivals and events", in: R. Raj and N.D. Morpeth (ed.), Religious Tourism and Pilgrimage Festivals Management: An International Perspective, Cambridge, CAB International, 2007.

- Egypt Touristic Guide, May 1996 (in Arabic).

- O. El-SHAL, "Archaeological and Environmental Solidarity Tourism for Developing the Egyptian Village in the Nile Delta", The 2011 TOSOK International Tourism Conference, organized by Tourism Sciences Society of Korea (TOSOK), Seoul, 4-6 July 2011.

- D. FENNELL, Ecotourism, $3^{\text {rd }}$ ed., New York, Routledge, 2008.

- H.J. GIBSON, "Sport Tourism: A Critical Analysis of Research”, Sport Management Review 1 (1), 1998, p. 45-76.

- N. Grimal, Histoire de l'Egypte ancienne, Paris, Fayard, 1988.

- F. HASSAN, "Relations culturelles entre l'Égypte et ses voisins orientaux durant la Préhistoire récente", in Le Sinaï durant l'antiquité et le Moyen Âge : 4000 ans d'histoire pour un désert, Actes du colloque «Sinaï » UNESCO from 19 to 21 september 1997, Paris, Errance, 1998.

- R.K. HITCHCOCK , "Cultural, Economic, and Environmental Impacts on Tourism Among Kalahari Bushmen”, in E. Chambers (ed.), Tourism and Culture. An Applied Perspective. New York, State University of New York Press, 1997.

- V. Lefebvre, S.G. Miller, and A. Chaouni, Desert Tourism: Tracing the Fragile Edges of Development, Harvard University Press, 2011.

- J. LOZACH, Le Delta du Nil. Étude de géographie humaine, Le Caire, Société Royale de Géographie d'Égypte, 1935.

- C. MAYEUR-JAOUEN, Histoire d'un pèlerinage légendaire en Islam, Paris, Aubier, 2004.

- Ministry of Information, Service of Information of States, Arab Republic of Egypt, The Annual Book 2009, Cairo: Service of Information of States Publications.

- The Impact of Culture on Tourism, OECD, Paris, French translation of pp. 3-75, only available on Internet (November $15^{\text {th }} 2012$ ).

- D. H. OlSEN and D.J. TIMOTHY, "Tourism and religious journeys", in D.J. Timothy and D. H. Olsen, Tourism, religion and spiritual journeys, New York, Routledge, 2006.

- D. Pages-El Karoui, Villes du delta du Nil: Tantâ, Mahalla, Mansûra, cités de la densité. Le Caire: CEDEJ, 2008.

- S. SCHIELKE, "On snacks and saints: when discourses of rationality and order enter the Egyptian mawlid", Archives de Sciences Sociales des Religions 135, 2006, p. 117-140.

- Ministry of Information, Service of Information of States. Arab Republic of Egypt, The Annual Book 2009. Cairo: Service of Information of States Publications. 
- D.J. Timothy, Cultural Heritage and Tourism. An Introduction, Charlesworth, 2011.

- D.J. Timothy and G.P. Nyaupane, Cultural Heritage and Tourism in the Developing World: A Regional Perspective, New York, Routledge, 2009. of-a-new-paradigm-for-healthcare-MTc1NjY1NjY=.htm (April 22 ${ }^{\text {nd }} 2012$ )

- United Nations Environment Program, Tourism and Deserts: A Practical Guide to Managing the Social and Environmental Impacts in the Desert Recreation Sector, 2006.

- D. VAlbelle, Les neuf arcs. L'Égyptien et les étrangers de la préhistoire à la conquête d'Alexandre, Paris, Armand Colin, 1990.

- M. WEED, Sport \& Tourism: A Reader, New York, Routledge, 2008.

\section{Web Sites}

- www.dakahliya.gov.eg/tourism.htm $\left(23^{\text {rd }}\right.$ September 2011)

- www.dar-sirr.com/Badawi.html (22 nd April 2012)

- $\quad$ www.egypttourism.org (22 ${ }^{\text {nd }}$ April 2012)

- www.en.egypt.travel (2012)

- $\quad$ www.evaneos.com/egypte (22 $2^{\text {nd }}$ April 2012)

- www.icomos.org/tourism/ (April 22 $2^{\text {nd }} 2012$ )

- www.ncbi.nlm.nih.gov/entrez/query.fcgi?cmd=Retrieve $\& d b=P u b M e d \& l i s t \_u i d s=$ $16791608 \&$ dopt $=$ Abstract $\left(22^{\text {nd }}\right.$ April 2012)

- www.planetware.com/tourist-attractions/egypt/behbeit-el-hagara-egy-daqbehhag.htm (November $11^{\text {th }}$ 2011)

- www.sis.gov.eg/En/Tourism/Egyptall/Enviormental/ (November $11^{\text {th }} 2011$ )

- www.sis.gov.eg/En/Story (June $2^{\text {nd }} 2012$ )

- www.sis.gov.eg/En/FourStTemplate.aspx?Category_ID=436 (February $22^{\text {nd }} 2012$ ).

- $\quad$ www.sis.gov.eg/En/Story.aspx?sid=1058 (23 ${ }^{\text {rd }}$ May 2012)

- www.sharkia.gov.eg/gov_achiev_tour.asp $\left(23^{\text {rd }}\right.$ May 2012)

- www.touregypt.net/delta2.htm (November $\left.10^{\text {th }} 2011\right)$

- www.touregypt.net/holyfamily3.htm (November 10 ${ }^{\text {th }} 2011$ )

- www.touregypt.net/parks (23 ${ }^{\text {rd }}$ May 2012)

- www.tourism.egnet.net/culture/museums_Egy.asp (November $10^{\text {th }} 2011$ )

- www.traveldoctoronline.net/medical-tourism-and-reproductive-outsourcing--thedawning-

* * * $*$

